範囲が虚血に陥った筋肉量を反映し，重要な予後を左右 する因子と考えられた。

Saddle embolism の症例飞行った washout 法は, roller pump を用いて虚血肢を急速大量に洗浄すること で, toxic substance を washout し，血流再開を契機 におこるこれらの物質の多臟器に与える障害を避け， MNMS の重症化の予防につながる一手段と考えられ た.
以上よりわれわれは（図2)，広範囲虚血に対する安 易な血流再開は MNMS を増悪させ危険であると考え， 血行再建の適応は小範囲の血栓, 塞栓症または, 虚血が 広範囲であってあ側副血行のある血栓症とした，虚血が 24 時間を過ぎた広範囲にわたる塞栓症，および側副血 行の不良な血栓症には肢切断, また 24 時間以内の広範 囲の塞栓症に対しては，血流再開前に両下肢の washout を試みるという方針である。

26 急 性 動 脈 閉 塞 症

——くに MNMS の検討——

大分医科大学、第 2 外科

\title{
高崎英己葉玉哲生田中康一森義顕 岡敬二重光修調亟治
}

急性動脈閉塞症の臨床的検討を行うとともに，その合 併症である myonephropathic metabolic syndrome（以 下 MNMS と略す) 飞対する動物実験を行った。

\section{臨床}

1981 年 10 月より 1987 年 1 月までの急性動脈閉塞症 症例は 25 例で, 年秢は 34 歳より 87 歳まで平均 67 歳で，男性 19 例，女性 6 例であった。 その病因は血栓 症 16 例, 塞栓症 9 例で, 血栓症の原因として ASO が 最屯多く 12 例, bypass graft の閉塞 3 例, TAO 1 例 で，塞栓症の原因として心房細動 5 例，虚血性心疾患 3 例，動脈瘤 1 例であった（表 1 ). 25 例中血行再建を 行ったものは 19 例で，その閉塞部位は，腸骨大腿動脈 領域が最も多く 10 例, bypass graft の閉塞 3 例, 膝窩 動脈，銷骨下動脈がそれぞれ 2 例，腹部大動脈，上腕動 脈がそれぞれ1例であった. MNMS は，腹部大動脈と 腸骨大腿動脈領域の閉塞の 2 例にみられた。手術方法は 血栓塞栓の除去だけを行ったのが 11 例で，筋膜切開 は 4 例に併施した. bypass を加えたものが 3 例あり， MNMS の 2 例はいずれも筋膜切開を加えている. 術 後, 肢切断を要したあのは 1 例で, 死亡例は 3 例, 内訳 は心筋梗塞, 解離性大動脈瘤, MNMS のそれぞれ 1 例 であった（表 1 ). 発症加ら血行再建ない儿抗凝固療法 等の治療までの経過時間を検討すると, 血行再建を行っ
表 1 Nature of occlusion

\begin{tabular}{lc}
\hline Thrombosis & 12 \\
ASO & 3 \\
old bypass graft & 2 \\
TAO & 16 \\
total & \\
\hline Embolism & 5 \\
af & 3 \\
ishemic heart disease & 1 \\
aneurysm & 9 \\
total & \\
$\quad$ Procedure & 7 \\
Thrombectomy (Thr) & $4^{*}$ \\
Embolectomy & $3^{*} \bigcirc \triangle$ \\
Thr +Fasciotomy (Fas) & 3 \\
Thr + bypass & $1^{*} \bigcirc$ \\
Thr +Fas+bypass & 1 \\
Bypass & 19 \\
\hline Total &
\end{tabular}

* death, $\bigcirc$ MNMS, $\triangle$ Amputation

たものでは，24 時間以内 7 例，うち 2 例が術後に心筋 梗塞之解離性大動脈溜のために死亡し，2３日経過の 7 例のなかで 1 例が MNMS で死亡した． 4 日以降経 過の 5 例中 1 例が肢切断となったが他は救肢しえた. MNMS は 11 時間之 2 日経過の 2 症例に認められた。 血行再建を行わなかった 6 例のうち 3 例は，全身状態が 


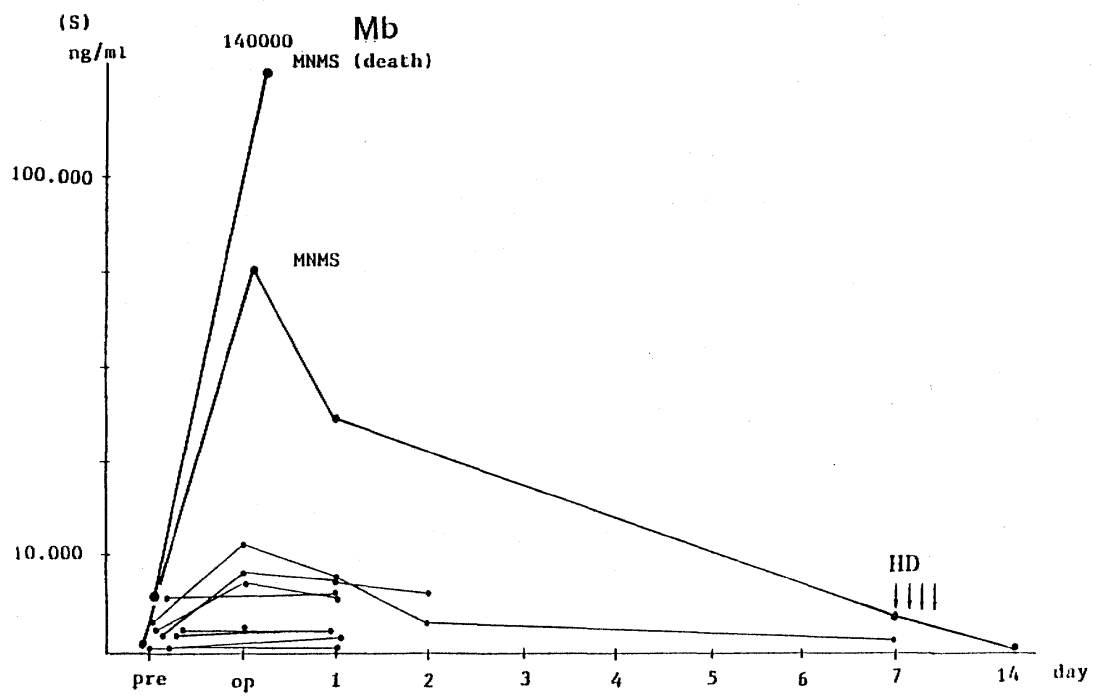

図 1

悪すざたために手術を断念せざるをえなかった症例で, 全例入院中に心筋梗塞で死亡した. 他の 3 例は, 末梢 レベルの閉塞で, 抗凝固療法のみで救肢しえた。当科で は，全身状態の許す限り，患肢の知覚の完全消失してい ない症例は積極的に血行再建を行う方針としている.

MNMS は血行再建の 19 例中 2 例 $11 \%$ に認められ た．その血中ミオグロビン（以下 $\mathrm{Mb}$ 之略す）の動向 は, 調べえた 10 症例につき検討すると, 全症例とも 術直後に Mb の peak がみられ以後漸減している. MNMS の 1 例は，高位腹部大動脈領域の閉塞で，血行 再建の 2 時間後に死亡した。 その $\max -\mathrm{Mb}$ 值は 14 万 $\mathrm{ng} / \mathrm{ml}$ であった，また，手 1 例の MNMS は術後 non oligoric uremia で, 尿量は十分であるが BUN, Cr の 上昇が著しく意識障害をきたし, 術後 1 週間目より 4 回 血液透析を行っているが，透析からの離脱むでき救肢し えた. その $\max -\mathrm{Mb}$ 值は 8.2 万 $\mathrm{ng} / \mathrm{ml}$ で MNMS を 呈さなかった残り 8 症例の最高值は 1.2 万 $\mathrm{ng} / \mathrm{ml}$ であ った（図 1).MNMS で死亡した症例の腎組織を，酵素 抗体法にて観察すると, 多数の尿細管に $\mathrm{Mb}$ の沈着を 認め，また，尿細管は $\mathrm{Mb}$ で閉塞していた。

\section{実験}

当科での MNMS の 1 例は, 術後 2 時間で死亡した が，MNMS モデル犬を作成し，急性期の Mb 值と各酵 素值につき検討した. 実験モデルには雑種成犬を用い, 静脈麻醉下に開腹し腎動脈以下の分枝を深大腿動脈レべ ルまで結紮し，腎動脈直下の腹部大動脈と，両側の大腿
動脈の 3 力所を clamp し， 5 時間後（I群 3 匹）と 7 時 間後（II群 4 匹）に再開通させ，再開通後 3 時間まで測 定した，再開通後の犬の後肢はII群で 4 匹中 3 匹が著明 な浮腫と硬直を認めるが，I群では同様な所見は認めら れなかった.さらに静脈血中の $\mathrm{pH}, \mathrm{K}, \mathrm{CPK}, \mathrm{ALD}$ に ついてII群で検討すると， $\mathrm{pH}$ では再開通後に acidosis

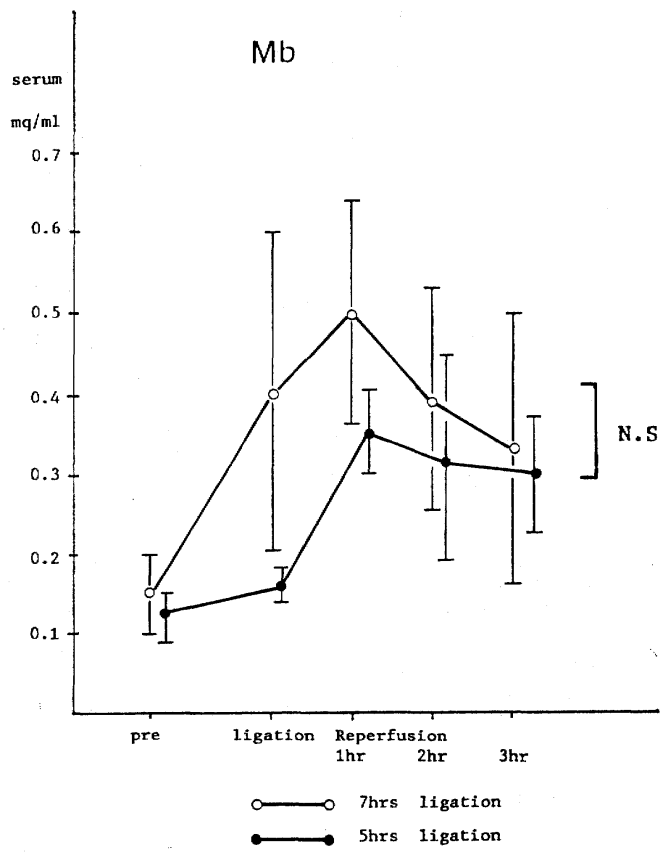

図 2 
の傾向を強めた， K, CPK，ALD についても再開通によ り上昇傾向は認めるが有意差はなかった。

犬 $\mathrm{Mb}$ は Theorell の変法により得た ${ }^{1}$. イヌ筋肉を ホモゲナイズし, その抽出液を DEAE sepharose によ るカラムクロマトグラフィーを行うと茶色と赤色の二つ のバンドを認める2). その elution pattern は小さいむ のを含めて四つの peak がみられ, その茶色の $\mathrm{Mb}$ 分画 部だけを抽出し，さらに superose にかけ，これを用い 家兔に兔疫を行い抗血清を得た. Mb の測定にはハイラ ンド社のレーザーネフェロメーターを用いた。 これは抗 原抗体複合物による光散乱強度により, 検体血清中の抗 原濃度を求めるあのである．Ｉ群とII群では，いずれす 再開通 1 時間後に peak がみられ, 以後は減少傾向を示
す. その $\mathrm{Mb}$ 值はI群で $\max \mathrm{Mb}$ 值は平均 $0.35 \mathrm{mg}$ / $\mathrm{ml}$, II 群で平均 $0.53 \mathrm{mg} / \mathrm{ml}$ でII群で高值の傾向は示す が有意差はなかった（図 2 ).

再開通 3 時間後に腎臓を摘出し, その組織を酵素抗体 法にて観察した. 尿細管中には多数の $\mathrm{Mb}$ の沈着を認 めた.

以上より 7 時間の高位腹部大動脈の clamp, 再開通に より MNMS モデル犬を作成するととができた.

臨床例や実験モデルであ, 血行再建後きわめて短い時 間で $\mathrm{Mb}$ により腎組織の変化が認められた. 血行再建 にあたり，早期の $\mathrm{Mb}$ 除去の方法が望まれる.

文 献 1) 母里正敏：日法医誌 $33: 63 ， 1979.2)$ Stone, M. J. : J. Clin. Invest. 56: 1334, 1975.

\title{
27 急性動脈閉塞症術後 myonephropathic-metabolic syndrome 発生予測因子および予後に関する検討
}

\author{
土浦協同病院 心臟血管外科 \\ 長岡秀郎印南隆一 榎本栄
}

急性動脈閉塞症に対する血行再建術後, 時に発生する myonephropathic-metabolic syndrome (MNMS) は生 命の危険を伴う重篤な合併症であるが，有効な治療法は 確立されていない，したがって本症の発生を術前に予測 して，乙れを回避しあるいは早期に治療を開始すること は治療成績向上のために重要なととと思われる，そこで 本研究では自験例を基に, 本症発生の予測因子および予 後について検索し若干の知見を得たので報告する次第で ある。

\section{対象亡方法}

対象は急性動脈閉塞症手術例 56 例であり, 男性 32 , 女性 24 例, 年齢は 27 から 93 歳におよび, 平均 64.6 歳であった。疾患の内訳は血栓症 44 , 塞栓症 10 , 外傷 性閉塞 2 例であり, 手術死亡は 4 例 (7.1\%) 認め, MNMS は8例 (14.3\%) 飞発症した。手術は全例に血 栓, 塞栓除去術を行い, 必要に応じて血管形成などを追 加し, 虚血時間 24 時間以上の例には下肢灌流 wash out 法を行った。

MNMS 8 例 (表 1) の年龄は平均 73.4 歳で 70 歳以 上が 8 例中 6 例を占め, 他の非 MNMS 例の 62.7 歳よ
り高歯であった，病因となった基礎疾患は表 1 のごとく であり，ASO による血栓症が半数を占めた．閉塞部位 は全例大腿動脈より高位閉塞であり，高位腹部大動脈閉 塞の 2 例は術前から MNMS を呈し, 高K血症により心 停止をきたし死亡した，また患肢所見では全例に知覚鈍 麻, 3 例に運動麻痺をみ, この3 例は手術死となった. 生存 3 例中 93 歳の 1 例は数回の血行再建術後, 遂に大 腿部切断に至った．急性閉塞発症から手術までの虚血時 間は 40 時間から 14 日に及び，3 日および 5 日経過 4 例 は手術死となった，虚血時間が 24 時間以内のものでは 高位腹部大動脈閉塞例を含めて MNMS 発症はなく, 手 術死亡皆無であった。

MNMS 例の 6 例 (M群)，および大腿動脈より高位閉 塞の非 MNMS (Control：C群) 11 例において血中, 尿中 myoglobin, CPK, GOT, 血清 creatinine そして血 小板数を経時的に測定し, MNMS 発生因子と思われる あのについて両群間の比較を行った.

\section{結果}

\section{1. 年齢 (歳)}

M群 $77.8 \pm 11.3, C$ 群 $70.2 \pm 6.9$ で両群間に有意差 